\title{
Short-Term and Long-Term Effects of Low and High Fat Diets on Lipid Profile and Acetylcholinesterase Activity in Different Brain Regions of Male Wistar Rats
}

\author{
Ebuehi, Osaretin A.T* and Adewolu, Abiodun \\ Department of Biochemistry, College of Medicine, University of Lagos, P.M.B. 12003, Lagos, Nigeria
}

*Corresponding Author: Ebuehi, Osaretin A.T, Department of Biochemistry, College of Medicine, University of Lagos, Lagos, Nigeria, Email: oebuehi@unilag.edu.ng

\begin{abstract}
High intake of saturated fat and cholesterol has been related to an increase risk of cardiovascular disease. Given their important role in neuronal function, there has been an increasing focus on altered lipid levels in brain disorder. In this study, the brain lipid profiles and acetylcholinesterase activity in 30 Wistar rats administered with low (8\% lard, 1.3\% cholesterol) and high (16\% lard, 2.5\% cholesterol) fat diets for two and four weeks were determined. High density lipoprotein cholesterol (HDL-C), total cholesterol (TC), triacylglycerol (TAG) and low density lipoprotein cholesterol (LDL-C) levels were determined using commercial diagnostic kits, while the activity of acetylcholinesterase was determined by Ellman's method. High fat diet (HFD) causes a significant decrease in high density lipoprotein cholesterol (HDL-C) in the plasma at both weeks when compared with the control ( $p<0.05)$. Total cholesterol (TC), triacylglycerol (TAG) and low density lipoprotein cholesterol (LDL-C) were significantly increase in the plasma of the experimental rats at four weeks when compared with the control ( $p<0.05)$. Significant increase was observed in HDL-C, TC, TAG and HDL-C in olfactory lobe, cerebellum and medulla oblongata at four weeks when compared with the control ( $p<0.05)$, while a significant decrease was observed in the cerebra lipid profile when compared with the control $(p<0.05)$. Low fat and high fat diets cause a significant increase in the activity of acetylcholinesterase in olfactory lobe, cerebrum, cerebellum and medulla oblongata at four weeks when compared with the control group ( $p<0.05)$. In conclusion, consumption of high dietary fat in this study alters brain lipid profile, and decrease brain acetylcholine level, therefore may contribute to progressive cognitive impairment.
\end{abstract}

\section{INTRODUCTION}

The brain is one of the most complex organs belonging to the central nervous system and is involved with perception, learning and memory, motion, and metabolic activities, which result from the communication between neurons in the brain, via a combination of electrical and chemical signals (Lovinger, 2008; Scheiffele, 2003). The brain is highly enriched in lipids, supporting structural, biochemical and cell signaling functions (O'Brien and Sampson, 1965). Bioactive lipids within the brain are shown to be pivotal for central nervous system homeostasis by modulating neurotransmission, synaptic plasticity, enzyme function, ion channel activities, gene expression and inflammation (Cermenati et al., 2015; Bazinet and Laye, 2014; Horrocks and Farooqui, 2004). Due to its important role, brain dysfunction may cause serious illness that deteriorates the quality of life. Changes in cerebral lipid homeostasis are widely reported to be associated with neurodegenerative disorders, and several studies also suggest significant changes in brain lipids with non-pathological ageing (Cunnane et al., 2012; Muller et al., 2015, Chan et al., 2012).

Chronic ingestion of Western styled diets enriched in saturated fats are causally associated with a range of neurodegenerative disorders including vascular dementia and Alzheimer's disease (Kanoskiand Davidson, 2011; Kalmijn et al., 1997). The mechanisms underpinning this association are not completely understood but broadly include capillary dysfunction; neurovascular inflammation; altered redox state and heightened oxidative stress (Breteler, 2000; Sparks et al., 2000; Hsu and Kanoski, 2014; Aung et al., 2016). With chronic ingestion of pro-inflammatory fat enriched diets, it is a reasonable proposition to suggest that changes of the brain lipidome may be realized and causally associated with some of the indicated 
mechanistic pathways. Cerebral sequelae that may reflect changes in the brain lipidome following long-term consumption of high-fat diets may be broad and include compromised insulin signaling (Benoit et al., 2009; Oh et al., 2013), neuronal apoptosis (Moraes, 2009), and poorer cognitive performance (Pipatpiboon et al., 2013; Greenwood and Winocur, 2001).

Furthermore, Acetylcholine (ACh) is a neurotransmitter that functions in conveying nerve impulses across synaptic clefts within the CNS (Tripathi and Sritvastava 2008). Following the transmission of an impulse across the synapse by the release of Ach, AChE is released into the synaptic cleft (Horton et al., 2006). This enzyme hydrolyzes $\mathrm{ACh}$ to choline and acetate and transmission of the nerve impulse is terminated (Liesener et al., 2007).

Cholinergic systems in the CNS play an important role in the learning and memory (Lena and Changeux, 1998; Levey et al., 1995). Acetylcholine (ACh) is required for cholinergic neurotransmission in the central and peripheral nervous systems (Goodman and Soliman, 1991). Acetylcholinesterase activity has been used as a marker for cholinergic activity. Acetylcholinesterase plays a very important role in the acetylcholine-cycle, including the release of acetylcholine (Kouniniotou and Tsakiris, 1989). The duration of action of acetylcholine at the synaptic clefts is critically dependent on acetylcholinesterase activity (Cooper et al., 2003). Acetylcholine plays an integral role in normal muscle functions, motor activity, attention, fear, anxiety and learning (Ferry et al., 1999; Fujimaki et al., 2000). Memory process is controlled through cholinergic interactions with their neurotransmitters (Ohno et al., 1997).

In the present work, we evaluated the short-term and long-term effects of low and high fat diets on the lipid profile and acetylcholinesterase activity in different brain regions of male Wistar rats.

\section{Materials AND MethodS}

\subsection{Experimental Animals}

Thirty male Wistar rats were used for this study with body weight ranging between 220- 250g. The rats were housed in clean plastic cages well ventilated, with 12 hours light/ dark cycle and acclimatized for two weeks. They were fed with standard rat pellet and water ad libitum.

\subsection{Reagents and Chemicals}

Ammonium ferrothiocyanate, chloroform, chloroform-methanol (2:1), $\mathrm{K}_{2} \mathrm{PO}_{4}$ (potassium diphosphate), TritinX-100, Diethyl ether, acetylthiocholine, distilled water, ethanol (97\%), HDL-C, cholesterol and triglyceride kits were procured from Sigma-Aldrich Chemicals, USA. All other chemicals and reagents were of the purest grade and were of an analytical grade.

\subsection{Diet Formulation}

The diet was formulated according to the modified method of Griffiths (1964), which is presented in Table 1 below;

The ingredients of the experimental diets were measured on a weighing balance, which were thoroughly mixed together and stored in a welllabelled plastic container appropriately.

Table 1. Composition of the experimental low and high fat diets

\begin{tabular}{|l|l|l|l|}
\hline \multicolumn{1}{|c|}{ Contents } & $\begin{array}{c}\text { Control } \\
\text { diet } \\
(\mathbf{g} / \mathbf{1 0 0 g})\end{array}$ & $\begin{array}{c}\text { Low fat } \\
\text { diet (LFD) } \\
(\mathbf{g} / \mathbf{1 0 0 g})\end{array}$ & $\begin{array}{c}\text { High fat } \\
\text { diet } \\
(\mathbf{H F D}) \\
(\mathbf{g} / \mathbf{1 0 0 g})\end{array}$ \\
\hline Wheat flour & 70.7 & 61.9 & 52.6 \\
\hline Milk powder & 23.6 & 23.1 & 23.2 \\
\hline $\begin{array}{l}\text { Dried yeast } \\
\text { powder }\end{array}$ & 3.5 & 3.5 & 3.5 \\
\hline $\begin{array}{l}\text { Sodium } \\
\text { Chloride }\end{array}$ & 1.2 & 1.2 & 1.2 \\
\hline Multivitamins & 1.0 & 1.0 & 1.0 \\
\hline $\begin{array}{l}\text { Cholesterol } \\
\text { powder }\end{array}$ & 0 & 1.3 & 2.5 \\
\hline Pork lard & 0 & 8 & 16 \\
\hline
\end{tabular}

\subsection{Experimental Design}

After acclimatization, the rats were randomly divided into three groups containing five rats each. Group one serves as the control group fed with control diet, while group two and three consist of rats fed with low and high fat diets respectively for two and four weeks.

\subsubsection{Animal Sacrifice and Sample Collection}

Animals were sacrificed at the end of two and four weeks of dietary fat administration, respectively, blood was collected from the animals by cardiac puncture under light anaesthesia after an overnight fast, the blood collected was transferred immediately into a heparinized tube to prevent blood cloting.

Olfactory lobe, cerebrum, cerebellum and medulla oblongata were excised using scissors 
and forcept from the intact brain, a representative from each group was placed in $10 \%$ formalin for histology, while others were placed in Eppendorf tubes and were stored at $4^{\circ} \mathrm{C}$ until they were homogenized.

\subsubsection{Separation of plasma from red blood cell}

The blood samples were then centrifuged at 4,000rpm for 10 minutes to separate the plasma from red blood cell. The supernatant was the plasma and it was kept in a clean eppendorf tubes and stored at $-4^{\circ} \mathrm{C}$ for further analysis.

\subsubsection{Homogenization and Extraction of Lipid}

Ten percent homogenate of the tissues was prepared by homogenising $0.2 \mathrm{~g}$ of tissues in $1.8 \mathrm{ml}$ of chloroform: methanol mixture $(2: 1 \mathrm{v} / \mathrm{v})$. The homogenate was centrifuged at 4000rpm for 10 minutes; the resulting supernatant was then washed with $200 \mu \mathrm{l}$ of $\mathrm{KCl}$ and recentrifuged for 5 minutes to obtain the lipid extract (Folch et al., 1957).

\subsubsection{Lipid Assay}

The concentrations of plasma and brain HDL-C, TC, TAG and LDL-C were determined using commercial diagnostic kits from Sigma-Aldrich Chemicals, USA.

\subsubsection{Determination of Acetylcholinesterase (AChE) Activity}

The method of AChE activity estimation is popularly known as Ellman's method named after George Ellman who developed this method in 1961 (Ellman et al., 1961). The esterase activity is measured by providing an artificial substrate, acetylthiocholine (ATC). Thiocholine released because of the cleavage of ATC by $\mathrm{AChE}$ is allowed to react with the - $\mathrm{SH}$ reagent 5,5'- dithiobis-(2-nitrobenzoic acid) (DTNB), which is reduced to thionitrobenzoic acid, a yellow coloured anion with an absorption maxima at $412 \mathrm{~nm}$. The extinction coefficient of the thionitrobenzoic acid is $1.36 \times 104 /$ molar/ centimeter. The concentration of thionitrobenzoic acid detected using a UV spectrophotometer is then taken as a direct estimate of the AChE activity.

\subsubsection{Histology of Brain regions}

Histological examination was based on earlier protocol (Humason, 1979). Brain regions were fixed in $10 \%$ formalin solution for $24 \mathrm{~h}$. All samples were then dehydrated in graded ethanol series, cleared in toluene and embedded in paraffin wax; 5-6 $\mu \mathrm{m}$ sections were routinely stained with Harris hematoxylin and eosins stains (Sigma-Aldrich) and were assessed under light microscope (Nikon Eclipse E400).

\subsubsection{Statistical Analysis of results}

Results are expressed as mean \pm standard error of the mean, and the differences among the experimental groups were analyzed using one way analysis of variance followed by Dunnet multiple comparisons with $p<0.05$ considered significant.

\section{RESULTS}

The experimental low and high fat diets was successfully formulated in accordance with the modified method of Griffiths (1964), as previously shown in Table 1 . The low fat diet is made up of $1.3 \%$ cholesterol powder and $8 \%$ of pork lard, while the high fat diet is made up of $2.5 \%$ cholesterol powder and $16 \%$ of pork lard.

\subsection{Plasma Lipid Profile}

Table 2. Plasma lipid profile of rats administered with low and high fat diets for two weeks

\begin{tabular}{|c|c|c|c|c|}
\hline $\begin{array}{c}\text { Gro } \\
\text { up }\end{array}$ & $\begin{array}{l}\text { HDL-C } \\
(\mathrm{mg} / \mathrm{dL})\end{array}$ & $\begin{array}{c}\text { TC } \\
(\mathrm{mg} / \mathrm{dL})\end{array}$ & $\begin{array}{c}\text { TAG } \\
(\mathrm{mg} / \mathrm{dL})\end{array}$ & $\begin{array}{c}\text { LDL-C } \\
(\mathrm{mg} / \mathrm{d} \\
\mathrm{L})\end{array}$ \\
\hline $\begin{array}{l}\text { Cont } \\
\text { rol }\end{array}$ & $\begin{array}{l}53.48 \pm 0 . \\
79\end{array}$ & $\begin{array}{l}54.25 \pm 0 . \\
70\end{array}$ & $\begin{array}{l}45.74 \pm 0 . \\
38\end{array}$ & $\begin{array}{l}29.27 \pm \\
0.41\end{array}$ \\
\hline LFD & $\begin{array}{l}4.37 \pm 0.1 \\
1^{*}\end{array}$ & $\begin{array}{l}10.25 \pm 0 . \\
04^{*}\end{array}$ & $\begin{array}{l}30.47 \pm 0 . \\
23^{*}\end{array}$ & $\begin{array}{l}4.76 \pm 0 . \\
04^{*}\end{array}$ \\
\hline HFD & $\begin{array}{l}0.39 \pm 0.0 \\
04^{*}\end{array}$ & $\begin{array}{l}90.99 \pm 2 . \\
05^{*}\end{array}$ & $\begin{array}{l}26.60 \pm 0 . \\
31^{*}\end{array}$ & $\begin{array}{l}25.40 \pm \\
0.49^{*}\end{array}$ \\
\hline
\end{tabular}

Values represent mean \pm standard error of the mean $(n=5)$.

*Significantly different from the control group at $p<0.05$

\subsubsection{Lipid profile of brain regions at two weeks}

Table 3. Olfactory lobe lipid profile of rats administered with low and high fat diets for two weeks

\begin{tabular}{|c|c|c|c|c|}
\hline $\begin{array}{l}\text { Grou } \\
\text { p }\end{array}$ & $\begin{array}{l}\text { HDL- } \\
\text { C } \\
(\mathrm{mg} / \mathrm{d} \\
\mathrm{L})\end{array}$ & $\begin{array}{l}\text { TC } \\
(\mathrm{mg} / \mathrm{dL})\end{array}$ & $\begin{array}{l}\text { TAG } \\
(\mathrm{mg} / \mathrm{dL})\end{array}$ & $\begin{array}{l}\text { LDL-C } \\
\text { (mg/dL } \\
\text { ) }\end{array}$ \\
\hline $\begin{array}{l}\text { Contr } \\
\text { ol }\end{array}$ & $\begin{array}{l}96.56 \\
\pm 1.26\end{array}$ & $\begin{array}{l}203.91 \pm 2 \\
.76\end{array}$ & $\begin{array}{l}57.12 \pm 0 . \\
45\end{array}$ & $\begin{array}{l}82.37 \pm 1 \\
.19\end{array}$ \\
\hline LFD & $\begin{array}{l}25.32 \\
\pm \\
0.64^{*}\end{array}$ & $\begin{array}{l}52.01 \pm 1 \\
06^{*}\end{array}$ & $\begin{array}{l}23.00 \pm 0 . \\
25^{*}\end{array}$ & $\begin{array}{l}33.64 \pm 0 \\
.77^{*}\end{array}$ \\
\hline HFD & $\begin{array}{l}0.97 \pm \\
0.02^{*}\end{array}$ & $\begin{array}{l}10.63 \pm 0 . \\
01^{*}\end{array}$ & $\begin{array}{l}30.55 \pm 0 . \\
01^{*}\end{array}$ & $\begin{array}{l}6.19 \pm 0 . \\
02^{*}\end{array}$ \\
\hline
\end{tabular}

Values represent mean \pm standard error of the mean $(n=5)$. 
Short-Term and Long-Term Effects of Low and High Fat Diets on Lipid Profile and Acetylcholinesterase Activity in Different Brain Regions of Male Wistar Rats

*Significantly different from the control group at $p<0.05$

Table 4. Cerebrum lipid profile of rats administered with low and high fat diets for two weeks

\begin{tabular}{|l|l|l|l|l|}
\hline $\begin{array}{c}\text { Gro } \\
\text { up }\end{array}$ & $\begin{array}{c}\text { HDL-C } \\
(\mathbf{m g} / \mathbf{d L})\end{array}$ & $\begin{array}{c}\text { TC } \\
(\mathbf{m g} / \mathbf{d L})\end{array}$ & $\begin{array}{c}\text { TAG } \\
(\mathbf{m g} / \mathbf{d L})\end{array}$ & $\begin{array}{l}\text { LDL-C } \\
(\mathbf{m g} / \mathbf{d L} \\
)\end{array}$ \\
\hline Cont & $53.48 \pm 0$ & $255.11 \pm$ & $82.25 \pm 0$ & 173.89 \\
rol & .79 & 3.73 & .29 & \pm 2.63 \\
\hline LFD & $4.37 \pm 0$. & $20.50 \pm 0$. & $64.31 \pm 0$ & $50.66 \pm$ \\
& $108^{*}$ & $22^{*}$ & $.51^{*}$ & $1.08^{*}$ \\
\hline HFD & $0.39 \pm 0$. & $15.08 \pm 0$. & $50.27 \pm 0$ & $8.51 \pm 0$. \\
& $004^{*}$ & $16^{*}$ & $.27^{*}$ & $102^{*}$ \\
\hline
\end{tabular}

Values represent mean \pm standard error of the mean $(n=5)$.

*Significantly different from the control group at $p<0.05$

Table 5. Cerebellum lipid profile of rats administered with low and high fat diets for two weeks

\begin{tabular}{|l|l|l|l|l|}
\hline $\begin{array}{c}\text { Gro } \\
\text { up }\end{array}$ & $\begin{array}{l}\text { HDL-C } \\
(\mathbf{m g} / \mathbf{d L})\end{array}$ & $\begin{array}{c}\text { TC } \\
(\mathbf{m g} / \mathbf{d L})\end{array}$ & $\begin{array}{c}\text { TAG } \\
(\mathbf{m g} / \mathbf{d L} \\
)\end{array}$ & $\begin{array}{l}\text { LDL-C } \\
(\mathbf{m g} / \mathbf{d L} \\
)\end{array}$ \\
\hline $\begin{array}{l}\text { Cont } \\
\text { rol }\end{array}$ & $19.72 \pm 0$. & $135.85 \pm$ & $83.67 \pm 0$ & 104.14 \\
\hline LFD & $9.47 \pm 0.2$ & $72.04 \pm 1$. & $73.47 \pm 0$ & $49.30 \pm$ \\
& $3^{*}$ & $09^{*}$ & .43 & $0.66^{*}$ \\
\hline HFD & $11.02 \pm 0$. & $56.26 \pm 1$. & $73.47 \pm 0$ & $8.51 \pm 0$. \\
& $22^{*}$ & $18^{*}$ & .43 & $65^{*}$ \\
\hline
\end{tabular}

Values represent mean \pm standard error of the mean $(n=5)$.

*Significantly different from the control group at $p<0.05$

Table 6. Medulla oblongata lipid profile of rats administered with low and high fat diets for twoweeks

\begin{tabular}{|c|c|c|c|c|}
\hline $\begin{array}{c}\text { Gro } \\
\text { up }\end{array}$ & $\begin{array}{l}\text { HDL-C } \\
(\mathrm{mg} / \mathrm{dL})\end{array}$ & $\begin{array}{c}\mathrm{TC} \\
(\mathrm{mg} / \mathrm{dL})\end{array}$ & $\begin{array}{c}\text { TAG } \\
(\mathrm{mg} / \mathrm{dL})\end{array}$ & $\begin{array}{c}\text { LDL-C } \\
\text { (mg/dL }\end{array}$ \\
\hline $\begin{array}{l}\text { Cont } \\
\text { rol }\end{array}$ & $\begin{array}{l}21.54 \pm 0 . \\
29\end{array}$ & $\begin{array}{l}54.25 \pm 0 . \\
70\end{array}$ & $\begin{array}{l}45.74 \pm 0 . \\
38\end{array}$ & $\begin{array}{l}29.27 \pm \\
0.418\end{array}$ \\
\hline LFD & $\begin{array}{l}0.696 \pm 0 . \\
1^{*}\end{array}$ & $\begin{array}{l}10.25 \pm 0 . \\
04^{*}\end{array}$ & $\begin{array}{l}30.47 \pm 0 . \\
23^{*}\end{array}$ & $\begin{array}{l}4.76 \pm 0 . \\
04^{*}\end{array}$ \\
\hline HFD & $\begin{array}{l}54.25 \pm 1 . \\
39^{*}\end{array}$ & $\begin{array}{l}90.99 \pm 2 . \\
05^{*}\end{array}$ & $\begin{array}{l}26.53 \pm 0 . \\
31^{*}\end{array}$ & $\begin{array}{l}25.40 \pm \\
0.49\end{array}$ \\
\hline
\end{tabular}

Values represent mean \pm standard error of the mean $(n=5)$.

*Significantly different from the control group at $p<0.05$

\subsection{Plasma lipid profile at four weeks}

Table 7. Plasma lipid profile of rats administered with low and high fat diets for four weeks

\begin{tabular}{|l|l|l|l|l|}
\hline $\begin{array}{l}\text { Gro } \\
\text { up }\end{array}$ & $\begin{array}{l}\text { HDL-C } \\
(\mathbf{m g} / \mathbf{d L} \\
)\end{array}$ & $\begin{array}{l}\text { TC } \\
(\mathbf{m g} / \mathbf{d L})\end{array}$ & $\begin{array}{l}\text { TAG } \\
(\mathbf{m g} / \mathbf{d L} \\
)\end{array}$ & $\begin{array}{l}\text { LDL-C } \\
(\mathbf{m g} / \mathbf{d L} \\
)\end{array}$ \\
\hline Cont & $51.16 \pm 0$ & $251.66 \pm$ & $35.69 \pm 0$ & $120.57 \pm$ \\
rol & .35 & 2.51 & .28 & 1.42 \\
\hline LFD & $39.17 \pm 0$ & $319.03 \pm$ & $57.23 \pm 0$ & $162.33 \pm$ \\
& $.55^{*}$ & $1.67^{*}$ & $.29^{*}$ & $0.90^{*}$ \\
\hline HFD & $31.59 \pm 0$ & $397.14 \pm$ & $68.45 \pm 0$ & $235.5 \pm 0$ \\
& $.69^{*}$ & $0.49^{*}$ & $.39^{*}$ & $.91^{*}$ \\
\hline
\end{tabular}

Values represent mean \pm standard error of the mean $(n=5)$.

*Significantly different from the control group at $p<0.05$

\subsection{Lipid profile of brain regions at four weeks}

Table 8. Olfactory lobe lipid profile of rats administered with low and high fat diets for four weeks

\begin{tabular}{|l|l|l|l|l|}
\hline $\begin{array}{l}\text { Gro } \\
\text { up }\end{array}$ & $\begin{array}{l}\text { HDL-C } \\
(\mathbf{m g} / \mathbf{d L})\end{array}$ & $\begin{array}{l}\text { TC } \\
(\mathbf{m g} / \mathbf{d L})\end{array}$ & $\begin{array}{l}\text { TAG } \\
(\mathbf{m g} / \mathbf{d L} \\
)\end{array}$ & $\begin{array}{l}\text { LDL-C } \\
(\mathbf{m g} / \mathbf{d L} \\
)\end{array}$ \\
\hline $\begin{array}{l}\text { Cont } \\
\text { rol }\end{array}$ & $33.64 \pm 0$. & $115.55 \pm$ & $31.13 \pm 0$ & $85.19 \pm$ \\
\hline LFD & $64.97 \pm 0$. & $190.52 \pm$ & $65.35 \pm 0$ & $95.90 \pm$ \\
& $42^{*}$ & $0.71^{*}$ & $.68^{*}$ & $0.82^{*}$ \\
\hline HFD & $140.26 \pm$ & $290.68 \pm$ & $55.30 \pm 0$ & 125.41 \\
& $0.56^{*}$ & $0.68^{*}$ & $.41^{*}$ & $\pm 0.71^{*}$ \\
\hline
\end{tabular}

Values represent mean \pm standard error of the mean $(n=5)$.

*Significantly different from the control group at $p<0.05$

Table 9. Cerebrum lipid profile of rats administered with low and high fat diets for four weeks

\begin{tabular}{|l|l|l|l|l|}
\hline $\begin{array}{l}\text { Gro } \\
\text { up }\end{array}$ & $\begin{array}{l}\text { HDL-C } \\
(\mathbf{m g} / \mathbf{d L})\end{array}$ & $\begin{array}{l}\text { TC } \\
(\mathbf{m g} / \mathbf{d L})\end{array}$ & $\begin{array}{l}\text { TAG } \\
(\mathbf{m g} / \mathbf{d L} \\
)\end{array}$ & $\begin{array}{l}\text { LDL-C } \\
(\mathbf{m g} / \mathbf{d L} \\
)\end{array}$ \\
\hline $\begin{array}{l}\text { Cont } \\
\text { rol }\end{array}$ & $51.16 \pm 0$. & $347.64 \pm$ & $59.67 \pm 0$ & $268.18 \pm$ \\
\hline LFD & $39.17 \pm 0$. & 2.82 & .20 & 2.43 \\
& $55^{*}$ & 1.59 & $.64 .08 \pm 0$ & $271.97 \pm$ \\
\hline HFD & $31.59 \pm 0$. & $192.07 \pm$ & $38.01 \pm 0$ & 1.14 \\
& $68^{* *}$ & $3.50^{*}$ & $.42^{*}$ & $2.67^{*}$ \\
\hline
\end{tabular}

Values represent mean \pm standard error of the mean $(n=5)$.

*Significantly different from the control group at $p<0.05$

Table 10. Cerebellum lipid profile of rats administered with low and high fat diets for four weeks

\begin{tabular}{|l|l|l|l|l|}
\hline $\begin{array}{l}\text { Gro } \\
\text { up }\end{array}$ & $\begin{array}{l}\text { HDL-C } \\
\mathbf{( m g / d L} \\
)\end{array}$ & $\begin{array}{l}\text { TC } \\
(\mathbf{m g} / \mathbf{d L})\end{array}$ & $\begin{array}{l}\text { TAG } \\
(\mathbf{m g} / \mathbf{d L} \\
\mathbf{)}\end{array}$ & $\begin{array}{l}\text { LDL-C } \\
\mathbf{( m g / d L} \\
)\end{array}$ \\
\hline $\begin{array}{l}\text { Cont } \\
\text { rol }\end{array}$ & $35.67 \pm 0$ & $278.92 \pm$ & $28.34 \pm 0$ & $228.08 \pm$ \\
\hline
\end{tabular}


Short-Term and Long-Term Effects of Low and High Fat Diets on Lipid Profile and Acetylcholinesterase Activity in Different Brain Regions of Male Wistar Rats

\begin{tabular}{|l|l|l|l|l|}
\hline LFD & $74.43 \pm 0$ & $333.72 \pm$ & $64.58 \pm 0$ & $229.81 \pm$ \\
& $.80^{*}$ & $2.89^{*}$ & $.68^{*}$ & 2.19 \\
\hline HFD & $59.67 \pm 0$ & $332.06 \pm$ & $42.15 \pm 0$ & $252.01 \pm$ \\
& $.71^{*}$ & $3.86^{*}$ & $.45^{*}$ & $3.06^{*}$ \\
\hline
\end{tabular}

Values represent mean \pm standard error of the mean $(n=5)$.

*Significantly different from the control group at $p<0.05$

Table 11. Medulla oblongata lipid profile of rats administered with low and high fat diets for four weeks

\begin{tabular}{|l|l|l|l|l|}
\hline $\begin{array}{l}\text { Gro } \\
\text { up }\end{array}$ & $\begin{array}{l}\text { HDL-C } \\
(\mathbf{m g} / \mathbf{d L})\end{array}$ & $\begin{array}{l}\text { TC } \\
(\mathbf{m g} / \mathbf{d L})\end{array}$ & $\begin{array}{l}\text { TAG } \\
(\mathbf{m g} / \mathbf{d L} \\
\mathbf{)}\end{array}$ & $\begin{array}{l}\text { LDL-C } \\
(\mathbf{m g} / \mathbf{d L} \\
\mathbf{)}\end{array}$ \\
\hline Cont & $91.57 \pm 1$. & $251.66 \pm$ & $35.69 \pm 0$ & 120.57 \\
rol & 17 & 2.50 & .27 & \pm 1.41 \\
\hline LFD & $130.32 \pm$ & $319.02 \pm$ & $57.23 \pm 0$ & 162.34 \\
& $1.05^{*}$ & $1.67^{*}$ & $.29^{*}$ & $\pm 0.99^{*}$ \\
\hline HFD & $130.63 \pm$ & $397.14 \pm$ & $68.45 \pm 0$ & 235.50 \\
& $0.55^{*}$ & $0.49^{*}$ & $.39^{*}$ & $\pm 0.91^{*}$ \\
\hline
\end{tabular}

Values represent mean \pm standard error of the mean $(n=5)$.

*Significantly different from the control group at $p<0.05$

\subsection{Acetylcholinesterase Activity in brain regions at two and four weeks}

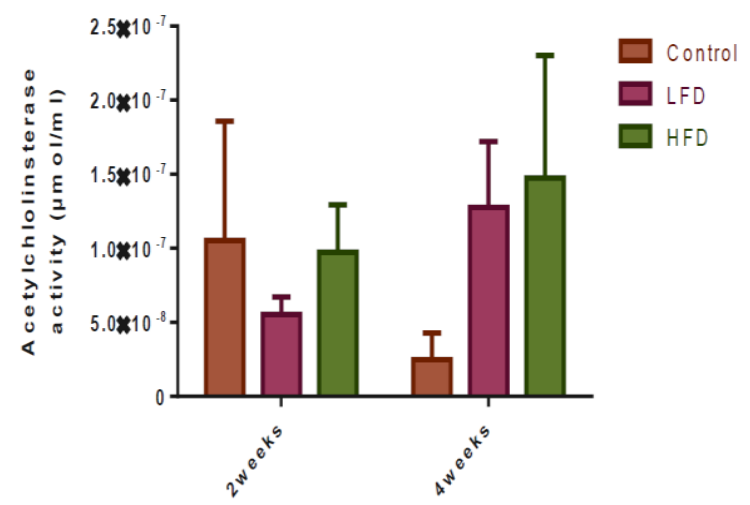

Figure 2. Olfactory lobe Acetylcholinesterase activity of rats administered with low and high fat diets

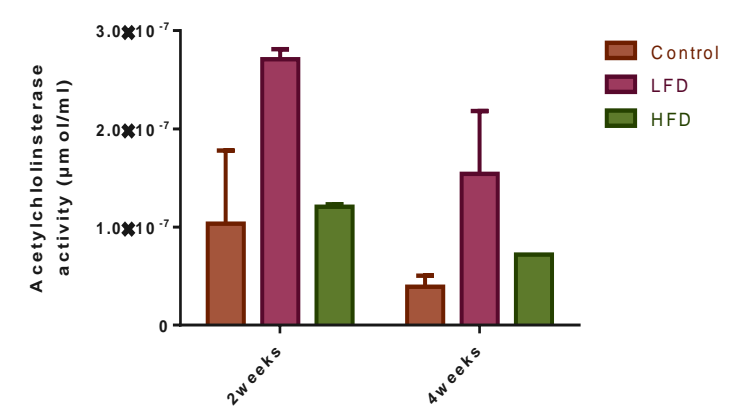

Figure 3. Cerebrum Acetylcholinesterase activity of rats administered with low and high fat diets

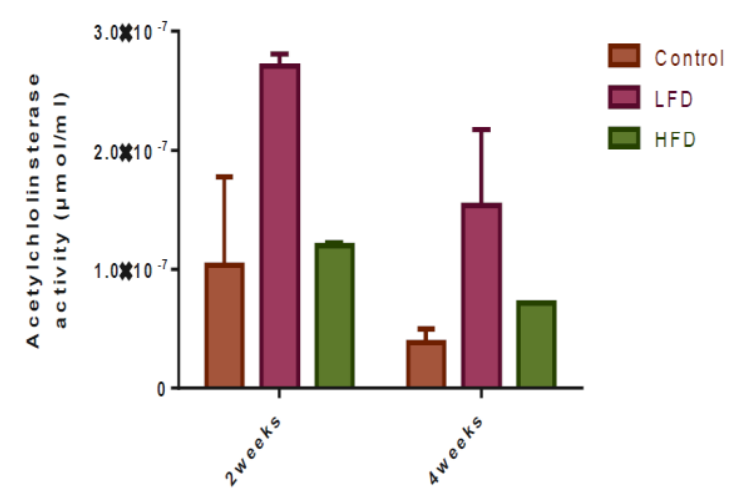

Figure 4. Cerebellum Acetylcholinesterase activity of rats administered with low and high fat diets

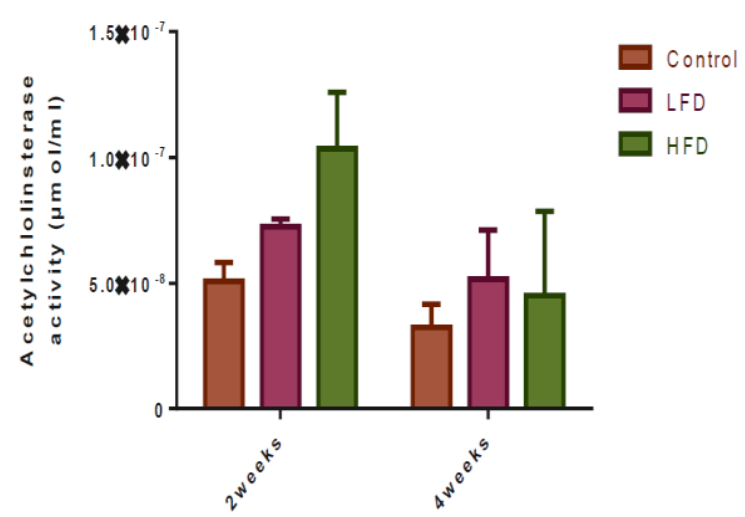

Figure 5. Medulla oblongata Acetylcholinesterase activity of rats administered with low and high fat diets

\subsection{Histological Analysis}
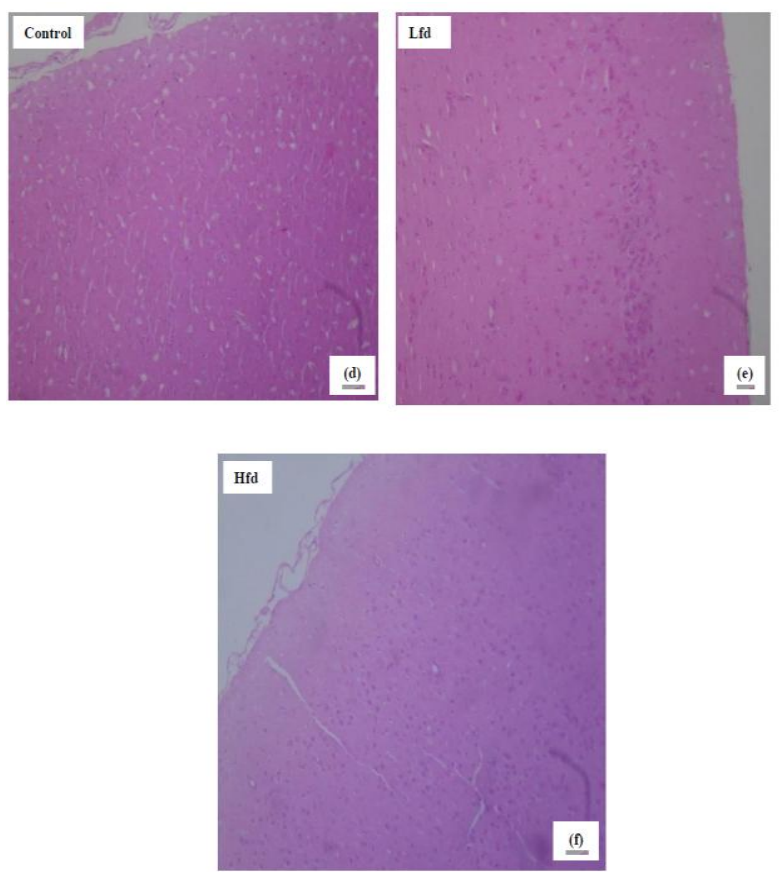

Figure 8(d). Photomicrograph of cerebrum showing neuronal cells on a background of neuropil at two weeks. No abnormalities are seen. (e) Photomicrograph of cerebrum showing neuronal cells on a background of neuropil at two weeks. No abnormalities are seen. (f): Photomicrograph of 
cerebrum showing neuronal cells on a background of neuropil at two weeks. No abnormalities are seen. (X40).
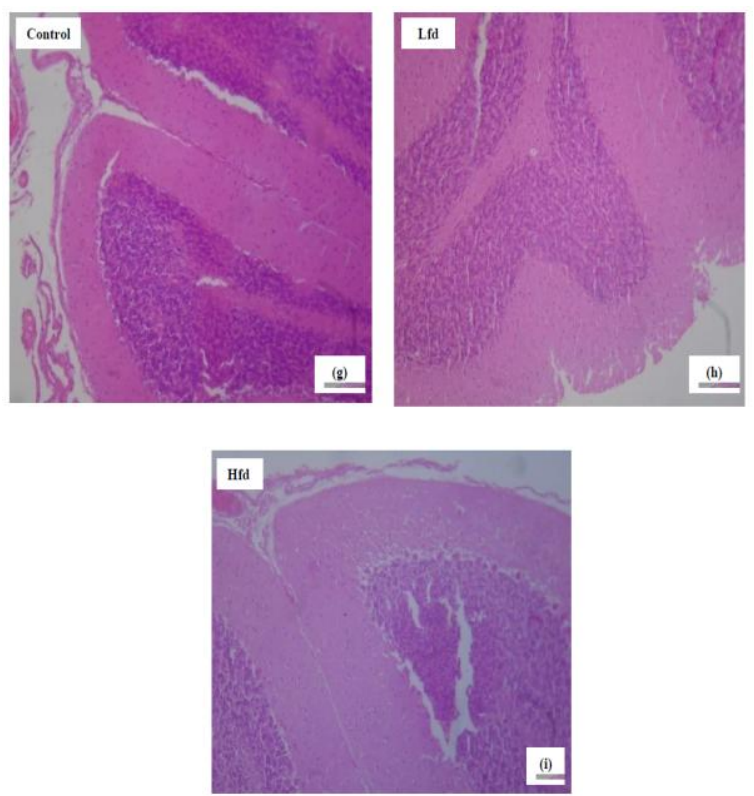

Figure 8 (g). Photomicrograph section of cerebellum shows cortex composed of molecular, ganglionic and granular layers, as well as a deeper medulla at two weeks. No abnormalities are seen.(h): Photomicrograph section ofcerebellum showing cortex composed of molecular, ganglionic and granular layers, as well as a deeper medulla at two weeks. No abnormalities are seen.(i): Photomicrograph section cerebellum showing cortex composed of molecular, ganglionic and granular layers, as well as a deeper medulla at two weeks. No abnormalities are seen. (X40).

\section{DISCUSSION}

High fat diet induced hyperlipidemia in rats including hypercholesterolemia and hypertriglyceridemia, which are major risk factors for the development of cardiovascular diseases (Makni et al., 2008). In this present study, administration of high fat diet for four weeks causes a significant increase in plasma total cholesterol and triacylglycerol concentration. The rise in plasma total cholesterol observed in this study could be attributed to increase in HMG-CoA reductase activity in the liver of animals fed with high fat diet and the reduced rate of the clearance of LDL from circulation due to defective LDL receptors, which is associated with increase of plasmatotal cholesterol concentration (Zulet et al.,1999). The significant risein plasma triacylglycerols level may beattributed to the decrease of activity oflipase which is an insulindependentenzyme involved in triglyceride clearancefrom plasma by mediating triglyceridelipolysis into glycerol and fatty acids (Yost et al., 1995). Another possibility is that suchsignificant increase in triglycerides might be a consequence of overproduction ofVLDL by the liver. These results are consistent with those achieved by Diaz et al., (2000) who reported that, rats fed with the high fat diet showed marked increase in plasma total cholesterol andtriacylglycerols.

In addition, a significant increase in plasma low density lipoprotein cholesterol (LDL-C) was observed after four weeks when comparedwith normal control group. These results are similar to those reported by Abdel-Maksoud et al., (2002) who reported that, mice and rats fed withhigh fat diet showed severe hypercholesterolemia,elevated plasma serum LDL-C and VLDLCcompared to those fed a normal diet. Yushchenko, (1959) recorded that, rabbitsfed on hyperlipidemic diet showedsignificant increase of the plasma lipidlevels; total lipids, total cholesterol,

triacylglycerols, and phospholipids. It should be noted that animals fed with normal diet had higher levels of triacylglycerol than then groups fed with low fat diet and high fat diet at two weeks. This may be due to the higher content of carbohydrate in the former diet as a consequence of its lower fat content, as shown in Table 1.

Elevated levels of plasma total cholesterol (TC), low-density lipoprotein cholesterol (LDL-C) and triglyceride (TG)as well as reduced levels of plasma high density lipoprotein cholesterol (HDL-C) are often associated with an increased risk of coronary heart disease (Smith et al., 2004).

The present study also shows that administration of high fat diet at four weeks significantly reduced the level of total cholesterol, high density lipoprotein cholesterol, triacylglycerol and low density lipoprotein cholesterol in the cerebrum. Cholesterol which is a major constituent of cell membranes modulates the physical properties of the brain which in turn affect the function of membrane proteins such as receptors and neuron transmission. More than a decade ago, Roses and colleagues demonstrated the existence of a genetic link between the risk of Alzheimer's diseases and the E4 allele of apolipoprotein $\mathrm{E}$, a protein involved involved in cholesterol homeostasis (Myers and Goate, 2001). In addition, lowering of cholesterol concentration may inhibit neuron transmission 
because neurons require cholesterol as building material for the assembly of presynaptic components such as synaptic vesicles (Porter, 2000).

The present study also shows that administration of high fat diet at four weeks significantly increase the level of high density lipoprotein cholesterol, total cholesterol and low density lipoprotein cholesterol in the olfactory lobe and medulla oblongata. These significant changes in the level of the lipid panel in the brain regions may be due to the disruption of the blood-brain barrier, which protects the brain from circulating blood. This barrier effectively prevents uptake of lipoprotein-bound cholesterol from the circulation, and de novo synthesis is considered to be responsible for practically all cholesterol in this organ. Such disruptions can result from consuming high-fat diet (HFD) and inflammation produced by alteration in brain vasculature resulted from chronic consumption of the high fat diets. The disruption of the permeability of blood-brain barrier, can make it vulnerable to systemic molecules that could trigger degenerative processes (Kanoski et al., 2010; Hsu and Kanoski, 2014).It has been documented that rabbits fed with a diet containing $2 \%$ cholesterol for 8 weeks, have demonstrated that such type of diet disrupts BBB permeability, alters vascularity, and induce vessels inflammation and $A \beta$ peptide accumulation in parenchyma; and this accumulation is similar to that observed in brains of AD patients (Sparks et al., 2008).

Acetylcholinesterase is an acetylcholine hydrolyzing enzyme that is responsible for the termination of cholinergic response. Acetylcholine as a neurotransmitter has a crucial role in the central nervous system and is implicated in behavioral as well as learning and memory and neurodegenerative diseases (Berger-Sweeney et al., 2003; Schliebs and Arendt, 2006). Acetylcholinesterase activation leads to a fast acetylcholine degradation and a subsequent down stimulation of ACh receptors causing undesirable effects on cognitive functions ( Soreq and Seidman 2001). Our results (Fig.4-7) show that the administration of low and high fat diets for four weeks caused an increase in the activities of acetylcholinesterase in the brain regions. This present finding is contradictory with previous reports on brain AChE activity in animal model of hypercholesterolemia (Paul and Borah, 2017). The differences in the results may be due to the time of exposure of the fat diets to the animals and composition of the diet.

Considering these findings, it can be speculated that increased AChE activity caused by longterm administration of low and high fat diets may lead to a reduction of cholinergic neurotransmission efficiency due to a decrease in ACh levels in the synaptic cleft, thus contributing to progressive cognitive impairment.

\section{CONCLUSION}

This study reveals that long-term feeding of high fat diet leads to changes in the lipid profile of the different brain regions in Wistar rats as a result of disruption of the blood-brain barrier, which protects the brain from circulating blood. The disruption of the permeability of bloodbrain barrier can make it vulnerable to systemic molecules which could trigger degenerative processes. Furthermore, the increase in the activity of acetylcholinesterase of the different brain regions as a result of administration of low and high fat diets for four weeks decrease the neurotransmitter, acetylcholine, and thus may contribute to progressive cognitive impairment.

\section{REFERENCES}

[1] Abdel-Maksoud, H. A. A., El-Senosi, A. Y. and Mahfouz, K.M. (2002). Biochemical effects of fish oil on lipid profile and glutathione redoxsystem of experimental hyperperlipidemia in albino rats. The Egyptian Journal of Biochemistry \& Molecular Biology. 141:12-14.

[2] Bazinet, R.P. and Laye, S. (2014). Polyunsaturated fatty acids and their metabolites in brain function and disease. NatRevNeurosci. 15(12):771-856.

[3] Benoit, S.C., Kemp, C.J., Elias, C.F., Abplanalp, W., Herman, J.P. and Migrenne, S. (2009). Palmitic acid mediates hypothalamic insulin resistance by altering PKC-theta subcellular localization in rodents. $J$ Clin Invest.119(9):2577-2666.

[4] Berger-Sweeney, J. (2003). The cholinergic basal forebrain system during development and its influence on cognitive processes: important questions and potential answers. $J$. NeurosciBehav Rev.27:401-411.

[5] Breteler, M.M. (2000). Vascular risk factors for Alzheimer's disease: an epidemiologic perspective. NeurobiolAging. 21 (2):153-210.

[6] Cermenati, G., Mitro, N., Audano, M., Melcangi, R.C., Crestani, M., De Fabiani, E. (2015). Lipids in the nervous system: from biochemistry and molecular biology to patho- 
physiology. Biochim BiophysActa.1851(1):51111.

[7] Chan, R.B., Oliveira, T.G., Cortes, E.P., Honig, L.S., Duff, K.E. and Small S.A. (2012).Comparative lipidomic analysis of mouse and human brain with Alzheimer disease.J BiolChem.287(4):2678-2766.

[8] Cooper, J.R., Bloom, F.E., and Roth, R.H. (2003).Acetylcholine, the biochemical basis of neuropharmacology.New York: Oxford University Press.pp.151-170.

[9] Cunnane, S.C., Schneider, J.A., Tangney, C., Tremblay-Mercier, J., Fortier, M., Bennett, D.A. (2012). Plasma and brain fatty acid profiles in mild cognitive impairment and Alzheimer's disease. $J$ Alzheimers Dis. 29(3):691-698.

[10] Diaz, M., Lopez, F., Hernandez, F.M. and Urbina, J.A. (2000). Carnitine effects onchemical composition of plasma lipoproteins of rabbits fed with normal and high cholesterol diets, Lipids, J.Biolo.Chem..35(6):632-637.

[11] Ferry, B., Roozendaal, B., and McGaugh, J.L. (1999). Role of norepinephrine in mediating stress hormone regulation of long-term memory storage: A critical involvement of the amygdala. Biological Psychia.46:1140-1152.

[12] Fujimaki, K., Morinobu, S., and Duman, R. (2000). Administration of a cAMP phosphodiesterase 4 inhibitor enhances antidepressant-induction of BDNF mRNA in rat hippocampus. Neuropsychopharmacology 22:42-51.

[13] Goodman, C.B., and Soliman, K.F. (1991).Altered brain cholinergic enzymes activity in the genetically obese rat.Experientia.47:833-835.

[14] Greenwood, C.E. and Winocur, G. (2001). Glucose treatment reduces memory deficits in young adult rats fed high-fatdiets. Neurobiol Learn Mem.75(2):179-268.

[15] Griffiths, L.A. (1964). Biochem, J. 92:173-179

[16] Horrocks, L.A. and Farooqui, A.A. (2004). Docosahexaenoic acid in the diet: its importance in maintenance and restorationof neural membrane function. Prostaglandins LeukotEssent Fatty Acids. 70(4):361-372.

[17] Horton, H.T., Moran, L.A., Scrimgeour, K.G., Perry, M.D. and Rawn, D.J. (2006).Principles of Biochemistry 4th ed. Pearson Int. ed. pp 147.

[18] Hsu, T.M. and Kanoski, S.E. (2014).Bloodbrain barrier disruption: mechanistic links between Western diet consumption and dementia. Front Aging Neurosci.6:88.

[19] Hsu, T.M. andKanoski, S.E. (2014). Bloodbrain barrier disruption: mechanistic links betweenWestern diet consumption and dementia. Front Aging Neurosci. 9(6):88-89.
[20] Humason, G.P. (1979). Animal tissue techniques. San Fransisco: W.H. Freeman and Company

[21] Kalmijn, S., Launer, L.J., Ott, A., Witteman, J.C., Hofman, A. and Breteler, M.M. (1997). Dietary fat intake and the risk of incident dementia in the Rotterdam Study.Ann Neurol.42(5):776-858.

[22] Kanoski, S.E. and Davidson, T.L. (2011). Western diet consumption and cognitive impairment: links to hippocampal dysfunction and obesity. PhysiolBehav.103(1):59-127.

[23] Kanoski, S.E., Zhang ,Y., Zheng, W. and Davidson, T.L. (2010). The effects of a highenergy diet onhippocampal function and bloodbrain barrier integrity in the rat. $J$ Alzheimers Dis. 21:207-219.

[24] Kouniniotou-Krontiri, P., and Tsakiris, S. (1989). Time dependence of $\mathrm{Li}+$ action on acetylcholinesterase activity in correlation with spontaneous quantal release of acetylcholine in rat diaphragm. Japanese Journal of Physio.39:429-440.

[25] Lena, C. and Changeux, J.P. (1998). Allosteric nicotinic receptors, human pathologies. Journal of Physio.92:63-74.

[26] Lovinger, D.M. (2008). Communication networks in the brain. Alcohol Res. Health 31:196-214.

[27] Makni, M., Fetoui, H.,Gargouri, N.K., Garoui el, M., Jaber, H., Makni, J.,Boudawara, T. and Zeghal, N. (2008). Hypolipidemicand hepatoprotective effects of flax and pumpkin seedmixture rich in omega- 3 and omega- 6 fatty acids in hypercholesterolemic rats. Food Chem Toxicol.46: 3714-3720.

[28] Moraes, J.C., Coope, A., Morari, J., Cintra, D.E., Roman, E.A. and Pauli, J.R. (2009). High-fat diet induces apoptosis of hypothalamic neurons. PLoSOne.4(4):50-55.

[29] Muller, C.P., Reichel, M., Muhle, C., Rhein, C., Gulbins, E. and Kornhuber, J. (2015). Brain membrane lipids in major depression and anxiety disorders. BiochimBiophysActa.1851(8):1052-1117.

[30] Myers, A.J. and Goate, A.M. (2001). The genetics of late -onset Alzheimer's disease. Curr.Opin. Neuro. 14:433-440.

[31] O'Brien, J.S. and Sampson, E.L. (1965). Lipid composition of the normal human brain: gray matter, white matter, and myelin. J. Lipid Res. 6(4): 537-581.

[32] Ohno, M., Kobayashi, M., Kishi, A., and Watanabe, S. (1997). Working memory failure by combined blockade of muscarinic and badrenergic transmission the rat hippocampus. Neuroreport.8:1571-1575. 
[33] Paul, R. and Borah, A. (2017). Global loss of acetylcholinesterase activity with mitochondrial complexes inhibition and inflammation in brain of hypercholesterolemic mice. J. Biol. Chem.,20: 282-291.

[34] Pipatpiboon, N., Pintana, H., Pratchayasakul, W., Chattipakorn, N. and Chattipakorn, S.C. (2013). DPP4-inhibitor improves neuronal insulin receptor function, brain mitochondrial function and cognitive function in rats with insulin resistance induced by high-fat diet consumption. Eur J Neurosci.37(5):839-888.

[35] Porter, F.D. (2000). RSH/Smitth-Lemli-Opitz syndrome: a multiple congenital anomaly/mental retardation syndrome due to an inborn error of cholesterol biosynthesis. Molecular Genetic Metabolism.71:163-174.

[36] Schliebs, R. and Arendt, T. (2006).The significance of the cholinergic system in the brain during aging and inAlzheimer's disease. J. Neural Transm. 113: 1625-1644.

[37] Smith, J.S.C., Jackson, R. and Pearson, T.A. (2004). Principles for national and regional guidelines on cardiovascular disease prevention: a scientific treatment from the World Heart and Stroke Forum. J.Circ. 109:3112-3121.
[38] Soreq, H. and Seidman,S. (2001). Acetylcholinesterase - new roles for an old actor. Nat Rev Neurosci.2:294-302.

[39] Sparks, D.L., Kuo, Y.M., Roher, A., Martin, T. and Lukas, R.J. (2000). Alterations of Alzheimer's disease in the cholesterol fed rabbit, including vascular inflammation. Preliminary observations. Ann Acad Sci.903:335-379.

[40] Spors, H., Albeanu, D. F., Murthy, V. N., Rinberg, D., Uchida, N., Wachowiak, M. and Friedrich, R. W. (2012). Illuminating Vertebrate Olfactory Processing. Journal of Neuroscience.32 (41):14102-14108.

[41] Tripathi, A. and Srivastava, U.C. (2008).Acetylcholineasterase: A versatile enzyme of the nervous system. Annals of Neurosci.15:106 - 110.

[42] Yost, T.J.,Froyd, K.K., Jenson, D.R. and Eckel, R.H. (1995). Changes in skeletallipoprotein lipase activity in response to insulin/glucose in non-insulin dependent diabetes mellitus. J.Metabolism. 44(6):786-790.

[43] Zulet, M.A., Barder, A., Garcin, H.,Higueret, P. and Martinez, J.A. (1999). Alterations in carbohydrate and lipid metabolism induced by a diet rich in coconut oil and cholesterol in a rat model. J. Am. Coll. Nutr. 18(1):36-42.

Citation: Short-Term and Long-Term Effects of Low and High Fat Diets on Lipid Profile and Acetylcholinesterase Activity in Different Brain Regions of Male Wistar Rats. Ebuehi, Osaretin A.T, Adewolu, Abiodun. ARC Journal of Neuroscience. 2020; 5(1):1-9. doi:dx.doi.org/10.20 431/2456-057X 0501001.

Copyright: (C) 2020 Authors. This is an open-access article distributed under the terms of the Creative Commons Attribution License, which permits unrestricted use, distribution, and reproduction in any medium, provided the original author and source are credited. 